\title{
BIAS GENDER DALAM KURIKULUM PENDIDIKAN DI PONDOK PESANTREN BUNTET DAN KEBON JAMBU BABAKAN CIWARINGIN CIREBON (Studi Kritis Fenomenologis Budaya Patriakhi)
}

\author{
GENDER BIAS IN EDUCATION CURRICULUM IN BUNTET \\ PESANTREN PONDOK AND KEBON JAMBU BABAKAN \\ CIWARINGIN CIREBON \\ (Critical Phenomenological Study of Patriarchal Culture)
}

\author{
Uyunul Ilmi ${ }^{1}$, Wakhit Hasim ${ }^{2}$ \\ IAIN Syekh Nurjati Cirebon ${ }^{1}$, IAIN Syekh Nurjati Cirebon ${ }^{2}$ \\ Uyunulilmi@gmail.com, ${ }^{1}$ wakhithasim@syekhnurjati.ac.id ${ }^{2}$
}

\begin{abstract}
ABSTRAK
Penelitian ini berkaitan dengan isi dan implementasi kurikulum pendidikan di Pesantren Buntet Kebon Jambu Babakan Ciwaringin Cirebon. Jenis penelitian ini adalah penelitian kualitatif (penelitian lapangan) dengan pendekatan fenomenologis. Teknik pengumpulan data yang digunakan adalah observasi, wawancara dan studi dokumentasi. Teknik analisis data yang digunakan adalah analisis kualitatif yang meliputi reduksi, penyajian data (penyajian data), dan verifikasi (penarikan kesimpulan). Dasar teoretis yang digunakan oleh penulis adalah teori ketidakadilan gender Mansour Fakih, yaitu subordinasi, marginalisasi, stereotip, kekerasan, dan beban ganda. Hasil penelitian ini menunjukkan bahwa ada bias gender, ini dapat dilihat dari komponen kurikulum yang memiliki empat jenis, yaitu tujuan, isi, strategi, dan evaluasi. Penulis menemukan tiga aspek bias gender dalam implementasi kurikulum pendidikan di pesantren Buntet dan Kebon Jambu.
\end{abstract}

Kata Kunci: Bias Gender, Komponen Kurikulum, Pesantren Buntet, Pesantren Kebon Jambu.

\begin{abstract}
This research relates to the content and implementation of the education curriculum at Pesantren Buntet Kebon Jambu Babakan Ciwaringin Cirebon. This type of research is a qualitative research (field research) with a phenomenological approach. Data collection techniques used were observation, interviews and documentation study. The data analysis technique used is a qualitative analysis which includes reduction, data display (data presentation), and verification (drawing conclusions). The theoretical basis used by the author is Mansour Fakih's gender injustice theory, namely subordination, marginalization, stereotype, violence and double burden. The results of this study indicate that there is a gender bias, this can be viewed from the curriculum components which have four types, namely the objectives, content, strategies, and evaluation. The author found three aspects of gender bias in the
\end{abstract}


Uyunul Ilmi | Bias Gender...

implementation of the education curriculum at the Buntet and Kebon Jambu boarding schools.

Keyword: gender bias, curriculum components, Pesantren Buntet, Pesantren Kebon Jambu

\section{PENDAHULUAN}

Ribuan tahun sebelum adanya Islam derajat perempuan sangatlah rendah, perempuan tidak mempunyai kemanusiaan yang utuh, tidak dapat berkarya dan menempuh jenjang pendidikan yang tinggi. ${ }^{1}$ Hal ini bisa dilihat dari peradaban-peradaban besar di dunia dahulu, seperti di Yunani, Romawi, India, dan Cina. Begitu juga agama-agama besar seperti Yahudi, Nasrani, Budha, Hindu dan lainnya yang ajaran agamanya tidak ada yang memberikan kehormatan dan kesetaraan terhadap perempuan. ${ }^{2}$

Dalam masyarakat elit Yunani, sebagaimana yang dijelaskan oleh Quraish Shihab dalam bukunya yang berjudul wawasan Al-Qur'an, wanita selalu ditempatkan (dikurung) di dalam istana-istana. Berbeda halnya dengan wanita-wanita yang berasal dari

\footnotetext{
${ }^{1}$ Musdah Mulia, Kemuliaan Perempuan Dalam Islam, (Jakarta : PT Elex Media Komputindo), 2014, Cet.Pertama, hlm 11
}

kalangan bawah, mereka akan diperjualbelikan, sedangkan yang berumah tangga mereka sepenuhnya berada di bawah wewenang laki-laki. Perempuan-perempuan tersebut juga tidak memiliki hak sipil, bahkan hak waris pun tidak ada. ${ }^{3}$

Sementara itu dalam peradaban Romawi, wanita sepenuhnya berada dalam pengawasan laki-laki, yakni ayah dan suaminya. Pengawasan tersebut mencakup hak untuk menjualnya, mengusir, menganiaya dan membunuh. Dalam agama Yahudi dan Nasrani pun kedudukan perempuan tidak jauh lebih baik. Kedudukan perempuan dalam ajaran Yahudi hanyalah sebagai pembantu. Mereka menganggap wanita sebagai suatu kesialan, hal ini disebabkan bahwa karena perempuanlah (Siti Hawa) yang membuat Nabi Adam terusir dari surga. Tidak jauh berbeda,

\footnotetext{
${ }^{2}$ M. Faisol, Hermeneutika Gender, (Malang : UIN MALIKI PRESS), 2011, cet.Pertama, hlm 38

3 Quraish Shihab dalam bukunya M. Faisol, Hermeneutika Gender, hlm 39
} 


\section{Uyunul Ilmi $\mid$ Bias Gender...}

dalam Agama Nasrani perempuan dijadikan sebagai senjata iblis untuk menyesatkan manusia. Bahkan mereka juga menganggap bahwa perempuan diciptakan semata-mata hanya untuk melayani laki-laki. ${ }^{4}$ Itulah beberapa gambaran akan kondisi perempuan praislam di mana martabat perempuan sangat rendah pada masa itu. sama halnya dengan martabat perempuan bagi masyarakat Arab Jahiliyah yang tidak jauh lebih buruk dari perdaban tersebut.

Salah satu tradisi Bangsa Arab pada masa jahiliyah adalah mengubur bayi perempuan secara hidup-hidup. Masyarakat Arab sangat malu jika dikaruniai bayi perempuan. Mereka beranggapan bahwa bayi perempuan adalah aib bagi keluarga, oleh karenanya mereka harus dibunuh. Tidak hanya itu perempuan juga hanya dijadikan sebagai pemuas hawa nafsu belaka, dipandang dari sisi fungsinya saja, sehingga jika salah satu fungsi tersebut hilang, kehormatannya pun terabaikan. Itulah kondisi perempuan sebelum datangnya

${ }^{4}$ Ibid, hlm 39

${ }^{5}$ Jefry Al-Bukhory, Ada Apa dengan "Wanita", (Jakara Selatan : Al-Mawardi Anggota IKAPI Jaya), 2008, Cet.ke-10, hlm 4 agama Islam. perempuan tidak mempunyai hak atau wewenang apapun, baik dari hak sipil maupun ahli waris. Perempuan hanya dijadikan sebagai budak, sebagai pembantu untuk melayani laki-laki. Kemudian Islam datang dan menghapuskan semua praktik-praktik yang merugikan untuk perempuan. $^{5}$

Islam datang untuk memperbaiki peradaban yang rusak, untuk membebaskan manusia dari semua sistem tirani, despotik, dan totaliter. Islam hadir untuk membangun masyarakat sipil yang berkeadaban (civil society) yaitu masyarakat yang mengamalkan nilai-nilai kemanusiaan universal, seperti halnya keadilan, kemaslahatan, kesetaraan, kejujuran dan kebenaran. ${ }^{6}$ Oleh karena itu, setelah Islam masuk barulah perempuan mempunyai peran dan kedudukan yang tidak kalah penting dengan laki-laki, yang awalnya mereka tidak mendapatkan hak waris, maka diberikanlah hak waris kepada mereka,

\footnotetext{
${ }^{6}$ Op.Cit., Musdah Mulia, Kemuliaan Perempuan Dalam Islam, hlm 6
} 
Jurnal Yaqzhan : Analisis Filsafat, Agama dan Kemanusiaan| Vol 5, No 2, Desember 2019

yaitu dua untuk laki-laki dan satu untuk perempuan. Jika tadinya, perempuan tidak mendapatkan hak untuk bersuara, menjadi boleh bersuara. Perempuan juga mendapatkan suatu kemuliaan khusus karena kaum laki-laki berkewajiban untuk senantiasa menjaga seorang wanita.

Islam merupakan agama yang rahmatan lil'alamin, yakni agama yang menebarkan cinta kasih dan kebaikan terhadap sesamanya. Tujuan utama diutusnya Nabi Muhammad Saw adalah perbaikan moral manusia. Berdasarkan hal tersebut, Nabi selalu menganjurkan kepada umat manusia untuk mengedepankan akhlak mulia, sikapsikap yang manusiawi atau berperikemanusiaan, santun dan beradab. Hal itulah yang menjadi penyebab bahwa Nabi menolak semua bentuk kezaliman, kekerasan, pemaksaan, dan perilaku diskriminatif. ${ }^{7}$ Terutama diskriminasi terhadap perempuan.

\footnotetext{
${ }^{7}$ Ibid., hlm 5

8 Hasil observasi penulis terhadap pandangan masyarakat desa Temukerep, Kec.Larangan, Kab.Brebes, yang selalu mengingatkan bahwa ia adalah seorang perempuan yang tidak perlu
}

Begitu halnya dengan pendidikan seorang perempuan yang seringkali dikaitkan dengan gender, "Perempuan tidak perlu sekolah tinggi-tinggi, karena pada akhirnya mereka akan mengurus dapur dan menjadi ibu rumah tangga". 8 Argumentasi yang menyatakan bahwa perempuan tidak perlu berpendidikan tinggi seperti di atas berkembang juga di lembaga-lembaga tradisional salah satunya adalah di pesantren. Hal ini dibuktikan oleh beberapa literatur dan film-film yang sudah dipublikasikan. Seperti halnya Film Berkalung Sorban yang dirilis pada tahun 2009 dan disutradarai oleh Hanung Bramantyo. Dalam literatur yang lain juga diceritakan yakni dalam buku karangan Buya Husein Muhammad yang berjudul Perempuan Islam dan Negara. ${ }^{9}$ Dalam buku ini dijelaskan bahwa perempuan dulunya sangat dilarang untuk menuntut ilmu di pesantren.

Dijelaskan oleh beberapa kiai alasan mengapa perempuan mengalami sikap yang berbeda di pesantren antara

berpendidikan tinggi, pada 15 Januari 2019, di Dukuh Temukerep Kecamatan Larangan Kabupaten Brebes

${ }^{9}$ Berdasarkan pengalaman penulis tinggal di Pesantren Buntet sejak tahun 2009-2019 
lain adalah sebagai berikut; pertama, beberapa kiai dan pengasuh pesantren yang dimintai pendapatnya mengatakan bahwa keengganan para pendiri pesantren untuk membuka pendidikan bagi perempuan dilatarbelakangi karena adanya suatu kekhawatiran tidak dapat menjaga mereka dengan baik. Kedua, kaum perempuan terutama yang masih gadis, perlu mendapatkan pengawasan yang sangat ketat supaya tidak menimbulkan fitnah bagi laki-laki. Oleh karenanya para kiai berpendapat bahwa mengasuh santri perempuan lebih sulit dan merepotkan ${ }^{10}$.

Oleh karena itu, pesantren hanya berisi laki-laki saja dan baru sekitar tahun 1920-an atau awal 1930-an, kaum perempuan mulai memasuki pesantren. Hal ini sesuai dengan penuturan salah satu tokoh muda NU. ${ }^{11}$ Menurut K.H Abdurrahman Wahid atau akrab disapa dengan Gus Dur, beliau mengemukakan bahwa dahulu perempuan masuk pesantren atau pun belajar di pesantren merupakan sesuatu

10 Husein Muhammad, Perempuan Islam dan Negara, (Yogyakarta : Qalam Nusantara, 2016) Cet.Pertama, hlm 32

${ }^{11}$ Ibid, hlm 29 yang tidak lazim dan menyalahi aturan agama. Oleh karenanya, tidak ada satupun pesantren yang menampung seorang siswi. Akan tetapi, Kiai Bisri yakni pengasuh pondok pesantren Denanyar Jombang merupakan satusatunya ulama yang menerima santri perempuan untuk pertama kali dan untuk belajar di pondok pesantren. Itu pun beliau lakukan secara sembunyibunyi. $^{12}$

Namun, seiring berjalannya waktu banyak pesantren-pesantren yang menerima perempuan, bahkan jumlah santri perempuan pun dapat dikatakan lebih banyak dari pada laki-laki, seperti halnya di pondok pesantren Buntet Astanajapura Cirebon, Pondok pesantren Kebon Jambu Babakan Ciwaringin Cirebon. Beberapa kiai juga mendirikan pesantren khusus untuk perempuan, seperti halnya pondok Pesantren Dar At-Tauhid yang diasuh oleh Buya Husein Muhammad dan lainnya. Setelah perempuan diakomodasi pesantren, nyatanya

\footnotetext{
${ }^{12}$ Abdurrahman Wahid dalam bukunya Husein Muhammad, Perempuan Islam dan Negara, hlm 30
} 
perbedaan-perbedaan tersebut tidak otomatis hilang. Hal ini bisa dilihat dari adanya pembedaan peraturan untuk perempuan dan laki-laki di pesantren, keikutsertaannya dalam organisasi, dan kurikulum pendidikan.

Pada umumnya sisi pembelajaran atau pun kurikulum antara pondok pesantren Buntet dan Kebon Jambu itu sama, hanya saja terdapat salah satu perbedaan yakni tidak adanya pelajaran yang bersifat aqliyah untuk perempuan yakni ilmu falaq, sedangkan ilmu falaq merupakan muatan lokal yang ada di madrasah aliyah berbasis pesantren yang hanya dipelajari di Madrasah Aliyah berbasis pesantren khusus putra. Sedangkan muatan lokal yang ada di putri hanyalah kitab-kitab yang menjelaskan tentang fiqih dan akhlak. Berdasarkan pemaparan di atas terdapat beberapa permasalahan yang penulis hadapi diantaranya mengapa perempuan selalu mendapatkan perbedaan, sekalipun sudah diakomodasi di pesantren? Mengapa perempuan mendapatkan kurikulum yang berbeda dari laki-laki?

13 Toto Syatori, Metodologi Penelitian Sebuah Pengantar, (Cirebon : Nurjati Press, 2011), Cet.Pertama, hlm 51
Apakah perempuan tidak mendapatkan pelajaran yang bersifat aqliyah itu terkait dengan anggapan bahwa perempuan itu lebih rendah atau memang minat perempuan memang lebih rendah dari lakilaki? Hal-hal itu yang menurut penulis belum jelas dan penulis akan melakukan riset di lapangan.

\section{METODOLOGI PENELITIAN}

Jenis penelitian dalam tulisan ini merupakan penelitian kualitatif (lapangan), yaitu suatu cara untuk mendapatkan pengetahuan dan memecahkan permasalahan yang dihadapi peneliti secara hati-hati dan sistematis di mana hasil dari data yang dikumpulkan bisa berbentuk rangkaian kalimat maupun narasi. ${ }^{13}$ Adapun jenis pendekatan kualitatif yang penulis pilih adalah fenomenologi. Fenomenologi menurut Husserl adalah sebuah metode yang menjelaskan segala sesuatu yang dengan suatu cara tertentu tampil dalam kesadaran manusia baik itu berupa hasil rekaan, maupun sesuatu yang nyata. ${ }^{14}$ Dalam definisi yang lain dijelaskan bahwa fenomenologi

\footnotetext{
${ }^{14}$ Imam Gunawan, Metode Penelitian Kualitatif Teori dan Praktik, Jakarta: Bumi Aksara, 2015, Cet.ke-3, hlm 71
} 
merupakan suatu metode yang mencoba mengungkap makna konsep atau sebuah fenomena pengalaman yang terjadi atas kesadaran beberapa individu maupun kelompok. ${ }^{15}$

Jadi, fenomenologi adalah sebuah metode untuk mengungkap sebuah fenomena pengalaman yang pernah dilakukan oleh manusia dengan kesadarannya, baik itu yang terjadi pada individu maupun kelompok. Metode ini akan digunakan penulis untuk melihat gejala-gejala budaya patriakhi yang mana mengindikasikan bias gender dalam kurikulum pendidikan di pondok pesantren Buntet dan Kebon Jambu Babakan Ciwaringin yang kemudian akan dianalisis menggunkan teori sosial gender Mansour Fakih.

\section{HASIL DAN PEMBAHASAN}

Tujuan riset penulis ini adalah untuk mengetahui faktor-faktor yang menjadi dasar pembedaan kurikulum antara laki-laki dan perempuan di pondok pesantren Buntet dan Kebon

15 Juliansyah Noor, Metodologi Penelitian Skripsi, Tesis, Disertasi, dan Karya Ilmiah, Jakarta: Kencana Prenada Media Group, 2011, Cet.Pertama, hlm 36
Jambu Babakan Ciwaringin Cirebon. Jadi, penulis akan menggunakan alat analisis yang berbicara mengenai pembedaan itu beserta penyebabpenyebabnya, dan alat analisis yang penulis akan gunakan adalah teori sosial gender oleh Mansour Fakih. Bias gender disini mempunyai arti pemihakan terhadap sesuatu secara tidak adil. Bias gender juga dapat diartikan sebagai pembagian terhadap sesuatu dengan porsi tidak adil antara laki-laki dan perempuan $^{16}$.

Adapun pembahasan mengenai bias gender di sini akan ditinjau dari keempat komponen kurikulum yang nantinya akan dianalisis menggunakan kelima aspek gender Mansour Fakih. Adapun kelima aspek tersebut adalah subordinasi, stereotype, marginalisasi, violence, dan double burden. Namun, sebelum membahas mengenai kelima aspek ketidakadilan gender tersebut, riset ini penulis awali dengan melihat, mengamati, dan menganalisis, mulai dari

\footnotetext{
${ }^{16}$ Sri Isnani Setyaningsih, Bias Gender Dalam Verba: Sebuah Kajian Leksison Dalam Bahasa Inggris, Jurnal Sawwa, Vol.11, No.01, Oktober 2015, hlm 30
} 
Jurnal Yaqzhan : Analisis Filsafat, Agama dan Kemanusiaan| Vol 5, No 2, Desember 2019

sarana dan prasarana, struktur organisasi, siswa, dan mata pelajaran.

\section{Sarana dan Prasarana}

Berdasarkan dari data yang sudah penulis peroleh dan dipaparkan pada bab dua, berkaitan dengan sarana dan prasarana terutama jumlah kamar mandi di Madrasah Aliyah Nahdlatul Ulama Putri Buntet adalah dua ruangan, dengan jumlah siswi kelesuruhannya kurang lebih sekitar lima ratus. Dengan tata letak berada dibawah tangga dekat gerbang masuk. Jumlah tersebut tidak seimbang dengan jumlah siswi yang sangat banyak, melihat hal ini maka banyak dari siswi-siwi MANU Putri yang ketika akan ke kamar mandi harus rela mengantri atau pulang ke pondok terlebih dahulu. Adapun, sedikitnya jumlah kamar mandi tersebut dikarenakan lahan MANU PUTRI yang tidak memadai, ditambah dengan sebagian ruangan sekolah madrasah Aliyah tersebut, digunakan untuk kegiatan belajar mengajar Mts NU Putri 3 yang notabennya masih kekurangan gedung.

Adapun dalam tata letak bangunan madrasah, di mana MANU
Putri mempunyai tiga tangga, satu tangga yang menjadi penghubung antara ruang kepala sekolah, bagian administrasi dengan ruang guru, dan satu tangga yang digunakan untuk menuju kelas yang berada di lantai dua, kemudia satu tangga yang lain digunakan untuk menuju lantai tiga. Dari ketiga tangga tersebut, terdapat satu tangga yang sedikit curam yang dapat dibilang sulit untuk dipakai, terlebih lagi jika ibu-ibu hamil, ia akan kesulitan melewati tangga tersebut. Hal ini bisa dilihat berdasarkan pengalaman penulis sewaktu masih belajar di madrasah tersebut di mana salah satu guru perempuannya yang sedang hamil, harus memilih untuk melewati tangga yang sering digunakan untuk anakanak dari pada melewati tangga yang berada di dalam kantor.

Berdasarkan hal ini, maka kita dapat melihat bahwa dalam segi sarana dan prasarana di MANU PUTRI belum sensitive gender, karena dalam proses pembangunanya tidak mempertimbangkan hal-hal yang berkaitan dengan gender. Begitu juga dengan jumlah kamar mandi 
yang sedikit, padahal jumlah siswi perempuan yang terbilang banyak itu sangat membutuhkan kamar mandi yang banyak pula, sebab di dalam diri perempuan ada yang namanya mestruasi dan lain-lain.

\section{Struktur Organisasi}

Dalam pembahasan mengenai struktur organisasi ini, penulis akan melihat apakah antara laki-laki dan perempuan sudah mendapatkan posisi yang adil di dalam suatu madrasah tersebut atau belum. Berdasarkan pengamatan dan hasil wawancara penulis, jumlah guru perempuan di Madrasah Aliyah Nahdlatul Ulama adalah yang sangat dominan, sedangkan laki-laki bisa dihitung yakni kurang lebih sekitar 5 orang. Hal ini disebabkan MANU Putri adalah sekolah aliyah berbasis pesantren yang didirikan khusus wanita, maka dalam penerimaan guru baru pun menurut penuturan kepala kurikulum yang dianjurkan adalah perempuan.

Bahkan, kedepannya MANU Putri ini akan dijadikan perempuan seluruhnya, baik itu dari kepala sekolah, kepala kurikulum, maupun tenaga pengajarnya. Akan tetapi, kalau sekarang masih belum bisa, karena perempuan pun belum ada yang bisa memegang menjadi kepala madrasah dan kepala kurikulum, hal ini sesuai dengan penuturan pak Fatchuddin selaku kepala kurikulum "kalo perempuan sudah ada yang bisa, sudah ada yang mampu memegang ini, nih saya serahkan semuanya untuk menjadi kepala kurikulum, tapi kan sampai saat ini juga belum ada yang bisa”. Oleh karena itu, sampai saat ini posisiposisi penting di dalam madrasah pun yang memegang adalah laki-laki.

Berdasarkan hal tersebut, maka dapat diketahui bahwa posisi-posisi perempuan berada pada tempat yang tidak penting, hal ini dikarenakan keahlian perempuan belum ada yang bisa memegang peranan tersebut.

\section{Siswa}

Dalam pembahasan mengenai bias gender dalam kurikulum pendidikan di pondok pesantren Buntet dan Kebon Jambu Babakan Ciwaringin Cirebon, maka jumlah siswa dan siswi juga menjadi tolak 
ukur untuk melihat adakah bias di dalamnya. Misalnya jumlah siswi terlalu banyak sedangkan jumlah siswa sedikit, ataupun sebaliknya. Namun, dalam hal ini penulis akan melihat dari sisi keikutsertaannya dalam organisasi-organisasi, seperti ketua osis dan ketua kelas. Berdasarkan observasi penulis di lapangan, meskipun MA Aliyah Tunas Pertiwi memberikan hak kepada siapapun untuk mengikuti dalam pemilihan ketua osis atau pun ketua kelas, namun hasil terpilih yang di dapatkan adalah laki-laki. Hal ini dikarenakan adanya perspektifperspektif bahwa laki-laki lebih mudah jika untuk berkomunikasi dengan siapapun, dan pihak perempuan pun lebih mempercayakan tugas tersebut kepada laki-laki bukan perempuan. Dari pemaparan tersebut maka dapat diketahui bahwa adanya bias itu terjadi karena perempuan sendiri lebih mempercayakan tugastugasnya kepada laki-laki.

\section{Mata Pelajaran}

Berkaitan dengan mata pelajaran, maka penulis akan melihat adakah bahan ajar, atau materi-materi yang dipelajari di kedua sekolah tersebut terdapat bias atau tidak. Dalam pembahsan mengenai mata pelajaran, berdasarkan hasil riset penulis mata pelajaran di sini terbagi menjadi dua, satu mata pelajaran umum, kedua muatan lokal. mata pelajaran umum ini, baik antara MANU Putri atau MA Tunas Pertiwi menyesuaikan dengan kurikulum pemerintah, yakni seperti Bahasa Indonesia, Geografi, Matematika, IPA, IPS, Ekonomi, Sosiologi, Bahasa Inggris dan lainnya. Sedangkan muatan lokal di sini merupakan unsur kepesantrenan yang menjadi ciri khas dalam madrasah tersebut.

Dalam hal ini, MANU Putri mempunyai ciri khas pada Fiqh wanita, di mana Fiqh wanita tersebut diambil atas dasar bahwa perempuan harus bisa berkontribusi di dalam masyarakat, dengan mengetahui posisinya dan problem-problemnya maka ia akan dapat memahami permasalahan yang ada pada dirinya, sehingga ketika ia sudah memhami dirinya ia pun akan dapat memahami orang lain. Oleh karenanya fiqh 
wanita sangat dikedepankan sebagai muatan lokal di sini. Adapun konten dalam pembelajarannya pun, mereka akan mempelajari hal-hal yang berkaitan dengan kewanitaan seperti halnya permasalahan haid, nifas, wiladah, Thaharah, sholat, bergaul dengan orang lain, dan menjadi istri yang sholeha di mana ia ditekankan supaya menjadi seorang istri yang patuh terhadap suaminya.

Di dalam pengambilan mata pelajaran tersebut, hal ini disesuaikan karena semua siswinya adalah perempuan, oleh karena itu fiqh wanita dijadikan sebagai muatan lokal di madrasah Aliyah Nahdlatul ulama putri Buntet. Hal itulah yang menjadi alasan bahwa MANU Putri tidak mengambil Ilmu Falaq sebagai muatan lokalnya. Berbeda dengan MA Tunas Pertiwi yang menjadikan kajian kitab kuning (Taqrib) dan Bahasa Arab sebagai muatan lokalnya. Tujuannya adalah supaya mereka dapat berkontribusi dalam pembelajaran di pondok ketika lulus nanti. Di ambilnya mata pelajaran tersebut pun disesuaikan juga dengan siswa dan siswinya yang memang tidak seluruhnya perempuan, tetapi juga terdapat laki-laki di dalamnya.

Berdasarkan pemaparan tersebut, maka dapat diketahui bahwa pembedaan mata pelajaran ini dikarenakan perbedaan gender. Setelah diketahui berdasarkan hasil observasi penulis dan pengamatan penulis, maka dapat dianalisis menggunakan kelima aspek ketidakadilan gender Mansour Fakih, yaitu:

a. Marginalisasi

Marginalisasi atau proses pemiskinan ekonomi dimana penghasilan kaum perempuan dinilai lebih rendah dari kaum laki-laki. Dari marginalisasi ini maka penulis akan melihat apakah ada marginalisasi dalam keempat aspek kurikulum, yakni tujuan, isi, strategi (metode), evaluasi dan di dalam sarana dan prasarana yang sudah penulis paparkan. Dalam hal ini penulis akan mengecek apakah ada penomorduaan pemikiran perempuan terkait dengan ekonomi yang terjadi dalam penentuan-penentuan kurikulum pendidikan di pondok pesantren Cirebon. Berdasarkan dari hasil temuan penulis, posisi 
perempuan termarginalkan karena kemampuannya yang tidak memenuhi peranan dalam menjadi kepala madrasah maupun kepala kurikulum, oleh karena itu posisi perempuan bertempat di tempat yang biasa-biasa saja. Hal tersebut terjadi di Madrasah Aliyah Nahdlatul Ulama Putri Buntet

b. Subordinasi

Subordinasi adalah anggapan tidak penting dalam ranah politik maupun publik. Dalam hal ini maka penulis akan melihat adakah penomorduaan perempuan yang terjadi dalam prosesproses seperti perumusan tujuan, isi, metode dan evaluasi. Misalnya adalah penulis akan melihat penomorduaan dalam hal mempraktikkan isi kurikulum atau strategi dalam pelaksanan tujuan yang akan dicapai di dalam kurikulum, di mana adakah kesenjangan dalam hal penyampaian argument dalam suatu forum kegiatan atau dalam pembelajaran dikelaskelas, yang berarti argument perempuan diikut sertakan atau dikesampingkan baik itu di dalam perumusan kurikulum maupun diskusi dalam suatu pelajaran. Jika memang argument-argument tersebut dikesampingkan, maka jelas bahwa ada aspek bias gender dalam pelaksanaan kurikulum pendidikan di lembaga tersebut.

Di dalam pelaksanaannya mungkin banyak yang tidak menyadari adanya bias gender di salah satu sekolah tersebut, hal ini bisa dilihat dari pengakuan siswa yang menyatakan sering mendapatkan perkataan bahwa argumennya itu tidak penting dalam suatu diskusi, meskipun hal tersebut dilakukan secara bercanda, namun, jika ditelaah terdapat adanya pembedaan tersebut terlihat dari anggapan tidak penting dalam suatu forum diskusi.

c. Stereotype

Pelabelan negatif atau stereotype, di sini penulis juga akan melihat adakah pelabelan-pelabelan negatif terhadap perempuan dalam pelaksanan empat komponen kurikulum, yakni tujuan, isi, strategi, dan evaluasi. Misalnya penulis akan melihat apakah ada kesenjangan di dalam pelaksanan isi kurikulum atau pelaksanan strategi dalam mewujudkan tujuan yang akan 
dicapai di dalam suatu kurikulum yang sudah disepakati. Contoh, di dalam pelaksanaan kurikulum yang berisi tentang materi-materi pengajaran, terutama pelajaran fiqih dan di dalam pengajaran tersebut kita ditekankan bahwa sebagai seorang perempuan, kita harus patuh dan nurut terhadap suami, karena perempuan yang baik adalah perempuan yang patuh terhadap lakilaki (suaminya). Melihat hal itu, maka jelas terdapat aspek gender dalam pelaksanaan kurikulum tersebut.

Contoh lainnya adalah anggapan bahwa seorang laki-laki harus menjadi yang terdepan bagi perempuan, hal ini dapat dilihat dari adanya ketua osis dan ketua kelas yang dominan laki-laki. Ketika salah seorang siswi MA Tunas Pertiwi ditanya, ketua osis terpilih laki-laki karena jika kaum adam dipandang lebih mudah untuk aksesnya ketika memanggil pengajar, dan lain-lain.

Adapun violence (kekerasan) dan double burden atau peran ganda tidak terlalu relevan dalam analisis kurikulum ini, hal ini dikarenakan bahwa double burden terkait dengan pembagian kerja antara laki-laki dan perempuan, baik itu di ruang publik maupun privat dan violence atau kekerasan. Dalam hal ini, kurikulum tidak berkaitan dengan itu. Oleh sebab itu, violence dan doubel burden tidak dijadikan alat analisis lagi untuk penulis, namun penulis tetap menggunakan ketiga aspek tersebut, yakni marginalisasi, subordinasi, dan stereotype.

\section{SIMPULAN}

Dari hasil penelitian yang telah dilakukan selama kurang lebih tiga bulan, terhitung dimulai pada bulan Mei 2019 sampai Agustus 2019 tentang Bias Gender Dalam Kurikulum Pendidikan Di Pondok Pesantren Cirebon (Pondok Pesantren Buntet dan Kebon Jambu Babakan Ciwaringin), dapat disimpulkan sebagai berikut:

1. Implementasi kurikulum di pondok pesantren Cirebon jika dilihat dalam empat aspek yakni pertama, perencanaan yang dimaksudkan di sini adalah proses dalam menyusun kurikulum. Dalam hal ini proses perumusan kurikulum pendidikan di MANU PUTRI merupakan 
momentum yang sangat penting, hal ini disebabkan karena dari proses perumusan tersebut akan didapatkan sebuah hasil yang nantinya diterapkan dalam kurikulum pendidikan. Adapun yang berperan dalam perumusan kurikulum, di antaranya adalah kepala madrasah, kepala kurikulum, dewan guru, dan yayasan. Peran penting dalam pembentukan tersebut dipegang oleh kepala madrasah dan kepala kurikulum.

Kedua, pelaksanaan, di dalam pelaksanaan kurikulum di MANU Putri dan MA Tunas Pertiwi, di samping tetap menjalankan kurikulum 2013, mereka juga tidak meninggalkan muatan lokal. Oleh karenanya implementasi kurikulum di sini, jika dilihat dari pelaksanaanya terbagi menjadi dua, yakni penambahan dan pengurangan jam pelajaran serta perlombaan sebagai praktik dalam muatan lokal. Ketiga, monitoring adalah melakukan pengecekan di pertengahan pada saat pelaksanaan kurikulum berlangsung, biasanya proses monitoring ini dapat dilihat dari pelaksaan Ujian Tengah Semesetr (UTS) dan Ujian Akhir Semester (UAS). Dari hasil ujianujian tersebut maka pihak sekolah mengadakan rapat, apakah hasil dari uji kompetensi siswa tersebut sudah mencapai target dari tujuan yang sudah ditetapkan atau tidak.

Keempat, evaluasi merupakan suatu proses untuk melihat atau mengecek apakah pelaksaan kurikulum berjalan dengan baik atau tidak. Sama halnya dengan monitoring, namun evaluasi biasanya ada di akhir. Pengecekan ini biasanya dilakukan melalui rapat antara kepala sekolah dan pengajar yang dilaksanakan dalam setiap satu tahun sekali, baik itu di MANU PUTRI maupun di MA Tunas Pertiwi.

2. Dalam pembahasan mengenai pembedaan kurikulum, terdapat dua faktor yang menyebabkan adanyan pembedaan tersebut. pertama adalah: Pertama, wewenang yayasan Dalam pembentukan kurikulum peran yayasan sangat berpengaruh, meskipun pada umumnya wewenang kepala sekolah dan kepala kurikulum juga 
ikut serta di dalamnya. namun, yang berhak menentukkan boleh atau tidaknya mata pelajaran itu ada dalam suatu kurikulum pendidikan adalah yayasan. Oleh karenan itu, yayasan di sini meskipun membebaskan dalam pemilihan kurikulum tambahan, akan tetapi juga turut serta menetapkan kebijakan dalam mengatur kurikulum tersebut baik atau tidaknya untuk madrasah.

Kedua, Kebutuhan Madrasah di sini adalah keinginan pada setiap madrasah kepada lulusannya supaya ketika keluar harus pandai dalam bidang apa. Misalnya adalah MANU PUTRI, dengan seluruh siswinya perempuan, maka kurikulum yang di ambil sebagai muatan kepesantrenan adalah berkaitan dengan kewanitaan, yaitu Fiqih wanita. Berbeda halnya MA Tunas Pertiwi yang mengedepankan pemahaman kitab kuning dan bahasa Arab. Tujuannya adalah supaya lulusan MA tersebut dapat melanjutkan pendidikannya ke jenjang yang lebih tinggi yakni ke luar negeri. Selain itu, karena madrasah tersebut berada dalam lingkup pesantren, maka pemahaman kitab kuning sangat ditekankan. Dengan harapannya adalah ketika anak didik itu telah selesai, maka ia sudah mampu membaca kitab kuning dan dapat berkontribusi dalam pengajaran di pondok jambu tersebut.

3. Berkaitan dengan bias gender, jika ditinjau dari komponen kurikulum yang terdapat empat macam, yaitu Tujuan, Isi, Strategi, dan Evaluasi, yang kemudian dianalisis menggunakan teori gender Mansour Fakih, yakni Subordinasi, Marginalisasi, dan Stereotype, penulis menemukan tiga aspek bias gender di dalam pelaksanaan kurikulum pendidikan di pondok pesantren Buntet dan Kebon Jambu Babakan Ciwaringin Cirebon. Ketiga aspek tersebut adalah Marginalisasi, subordinasi dan stereotype. Pertama, marginalisasi ini dapat dilihat dimana posisi perempuan termarginalkan dalam peranannya yang hanya menjadi tenaga kependidikan seperti biasa. Hal ini dikarenakan bahwa 
kemampuan perempuan dianggap belum memadai untuk dijadikan kepala sekolah maupun kepala kurikulum. Oleh karena itu, posisiposisi penting di dalam Madrasah Aliyah Nahdlatul Ulama Putri di isi oleh laki-laki.

Kedua, Subordinasi ini dapat dilihat dalam pelaksanaan kegiatan belajar mengajar di MA Tunas Pertiwi dimana tanpa di sadari bias gender itu ada, hal ini bisa dilihat bahwa adanya anggapan bahwa laki-laki yang lebih baik menjadi pemimpin, baik itu dalam suatu organisasi kesiswaan seperti OSIS maupun ketua kelas. Alasannya adalah lakilaki lebih dapat diandalkan dan dapat berkomunikasi dengan bebas kepada siapapun dibandingkan dengan perempuan.

Ketiga, stereotype dimana hal ini terjadi dalam pelaksanaan diskusi dimana argumen-argument perempuan masih dianggap tidak rasional.

\section{DAFTAR PUSTAKA}

Al-Bukhory Jefry. Ada Apa dengan "Wanita". Jakarta Selatan: AlMawardi Anggota IKAPI Jaya. Cet.10. 2008.

Faisol, M. Hermeneutika Gender. Malang: UIN MALIKI PRESS. Cet.I. 2011.

Fakhi, Mansour. Analisi Gender dan Transformasi Sosial. Yogyakarta: INSISTPress. Cet.16. 2016.

Gunawan, Imam. Metode Penelitian Kualitatif Teori dan Praktek. Jakarta: Bumi Aksara, 2015.

Juliansyah Noor, Metodologi Penelitian Skripsi, Tesis, Disertasi, dan Karya Ilmiah. Jakarta: Kencana Prenada Media Group. 2011.

Muhammad, Husein. Perempuan Islam dan Negara. Yogyakarta: Qalam Nusantara. Cet.I. 2016.

Muhammad, Husein. Fiqh Perempuan. Yogyakarta: IRCiSoD.2019.Cet.1.

Mulia Musdah. Kemuliaan Perempuan Dalam Islam. Jakarta: PT Elex Media Komputindo. Cet.I. 2014.

Syatori, Toto. Metodologi Penelitian Sebuah Pengantar. Cirebon: Nurjati Press. Cet.I. 2011. 